\title{
The Effect of Cooperative Learning Models and Achievement Motivation on the Ability to Read English Narrative Texts in Class VIII Students of SMP Negeri 41 Medan
}

\author{
Monica Aomari Ritonga; Julaga Situmorang; Dina Ampera \\ Department of Education Technology \\ State University of Medan \\ Medan, Indonesia \\ e-mail: monica.kristin@yahoo.com
}

\begin{abstract}
This study aims to find out: 1) the learning outcomes of English students who learned by using the CIRC learning model and the English learning outcomes of students who learned the STAD learning model; 2) the results of learning English between students with high achievement motivation levels and learning outcomes of students with low achievement motivation; 3) interaction between learning models (CIRC and STAD) and Achievement Motivation in influencing English learning outcomes. The research method used is a quasi $2 \times 2$ factorial design experiment. The results of the study concluded that: (1) the average English learning outcomes of students taught by the CIRC learning model were higher than the STAD learning model; (2) the average English learning outcomes of students who have higher achievement motivation are lower achievement motivation; (3) there is an interaction between the learning model and Achievement Motivation towards the results of learning English.
\end{abstract}

Keywords-Type of CIRC, STAD, Achievement Motivation and ability to read English narrative text.

\section{INTRODUCTION}

The learning model that has been implemented in SMP Negeri 41 Medan found that teachers in teaching English subjects are mostly conventional learning models that still refer to the lecture method. This is because the teacher thinks most of the English learning material is more precisely delivered by the lecture method. This is because learning English by placing students individually will be more conducive. Another method besides lectures is discussion by studying the material itself either through books or the internet. Although the teacher has implemented a group-based learning model, but learning has not been fully directed and well conditioned. Therefore, in the study group students do not fully participate and not a few students tend to be passive.

Based on the data obtained, it can be seen that the average UAS value is still low and still below the KKM value. This was allegedly caused by various factors including: students were less than optimal in understanding and reading English. Students still have difficulty in understanding the text and are unable to write it back, they read and answer questions without understanding the content of the reading as a whole, besides the lack of vocabulary mastery also hampers students' reading comprehension. In learning to read with conventional learning models the role of the teacher is more dominant, the teacher tells students to read texts, write difficult vocabulary meanings, and work on a number of questions. The use of conventional learning models is perceived to be less attractive to students' attention, making students passive and learning more dominated by teachers.

Cooperative Integrated Reading And Composition learning model (CIRC) is one of the learning models which initially integrated cooperative teaching read and write. In this model consists of three stages, the first is pre-reading which includes reading groups and introducing stories that children will read, reading stages which include reading in pairs, writing related stories and grammar stories, saying words loudly, and meaning said, and the post-read stage includes retelling stories, examining by a partner, and testing. While the STAD model cooperative learning model is the simplest, and is the best model for the beginning for new teachers using a cooperative approach. Teachers who use the STAD model refer to student group learning, present new academic information to students every week using verbal presentations or text. Considering these two types of learning models, efforts to determine the effectiveness of each of these learning models need to be researched so that the CIRC learning model is suitable and can be used as a guide in improving learning outcomes in English subjects at junior high schools in Medan.

In addition to the CIRC learning model that can improve the ability to read narrative texts in students' English, Achievement Motivation possessed by a student greatly influences the ability to read narrative texts in English in the classroom. If the student has Achievement Motivation in following learning activities, then he will be encouraged to do the task and do difficult activities but quite realistic in doing it, he will be persistent and never give up in every learning activity. He found this when the atmosphere of learning 
activities was very supportive and had high achievement motivation. Then the learning model used by a teacher in the classroom is closely related to the learning component related to Achievement Motivation.

According to research from Novika (2014) entitled "The Influence of Cooperative Integrated Reading and Composition Learning Models (CIRC) and the Ability to Read Narrative Writing Skills of Grade VII Students in Ngawi District". The purpose of this study was to determine the effect of learning models on learning achievement in English which was seen from the ability of students' narrative writing skills. The model compared is the CIRC cooperative learning model. Then this study was strengthened by Karim's (2016) research entitled "Application of CIRC Model Learning to improve the Learning Outcomes of Grade VIII Students Reading English Text and Essay in the Form of Descriptive Learning at SMP Negeri 3 Kluet Utara", with the results showing that the CIRC learning model has a positive impact in improving student learning outcomes in learning as indicated by the results of work sheets with some students, so that they become motivated to learn. This is in line with Putri's (2017) research entitled Cooperative Integrated Reading and Composition Model (CIRC) on Reading Comprehension Skills of Biographical Texts of Class VII Students of State Junior High School 1 Jetis Bantul "which said there was a significant influence between learning achievement on reading comprehension of biographical texts of students the learning uses the CIRC model with the learning achievement of reading the understanding of biographical texts of students whose learning uses the lecture method. By looking at the average learning using the CIRC model is higher than the average learning using the lecture method so that it can be said learning with the help of the CIRC model is more effective than learning using the lecture method.

In this study, various theories can be related to the influence of cooperative learning models and achievement motivation on students' English learning outcomes. Furthermore, the results of the research will be presented and the discussion is related to the theory of theory that has underlie this research. The reason for choosing the CIRC learning model and the STAD learning model is because the learning resources are not only teachers, but also students. Such conditions are expected to help students who have learning difficulties and can encourage students to complete each subject of the subject matter delivered by the teacher.

In connection with what has been explained above, the purpose of this study is (1) to know the ability to read narrative texts in English students who are taught with the Cooperative Integrated Reading And Composition learning model (CIRC) higher than students taught with Student Teams learning model Achievement Divisions (STAD) (2) to determine the ability to read narrative text in English students who have higher Achievement Motivation than students who have low Achievement Motivation (3) to know the interaction between Learning Model and Achievement Motivation on the ability to read narrative texts in English.

\section{Method AND Results MethoD}

This research was carried out at SMP Negeri 41 Medan. The population in this study were all eighth grade students of SMP Negeri 41 Medan with a total of 8 classes consisting of 240 students. The sampling technique in this study was cluster random sampling technique.

This study uses an experimental method with a quasi design $2 \times 2$ factorial design. Through this design compared the influence of CIRC learning model and STAD learning model on the ability to read narrative text in English in terms of student achievement motivation. These variables are then included in the research design as shown in Table 1.

\begin{tabular}{|c|c|c|}
\hline \multicolumn{3}{|c|}{ TABLE 1. Research Design } \\
\hline $\mathrm{A}$ & $\begin{array}{c}\text { CIRC } \\
\left(\mathrm{A}_{1}\right)\end{array}$ & $\begin{array}{c}\text { STAD } \\
\left(\mathrm{A}_{2}\right)\end{array}$ \\
\hline $\operatorname{High}\left(\mathrm{B}_{1}\right)$ & $\mathrm{A}_{1} \mathrm{~B}_{1}$ & $\mathrm{~A}_{2} \mathrm{~B}_{1}$ \\
\hline $\operatorname{Low}\left(\mathrm{B}_{2}\right)$ & $\mathrm{A}_{1} \mathrm{~B}_{2}$ & $\mathrm{~A}_{2} \mathrm{~B}_{2}$ \\
\hline
\end{tabular}

Information:

A1B1: Ability to read English narrative text groups of students treated with CIRC learning models that have high achievement motivation

A2B1: Ability to read English narrative text groups of students treated with STAD learning models that have high achievement motivation

A1B2: Ability to read English narrative text groups of students treated with CIRC learning models that have low achievement motivation

A2B2: Ability to read English narrative text groups of students treated with STAD learning models that have low achievement motivation.

The data analysis technique used is descriptive and inferential statistical techniques. Descriptive statistical techniques are used to describe the data including: average value, median, mode, variance and standard deviation. The inferential technique that will be used is variance data analysis (ANAVA) technique $2 \times 2$. Hypothesis testing is carried out at a significance level of 5\%. Before the two-way ANAVA was carried out, the analysis of the requirement test was done, namely the normality test using the Liliefors test and homogeneity test using the Fisher test and Bartlett test.

Furthermore, for the purposes of testing hypotheses, the following statistical hypothesis is formulated:

Hypothesis I $\quad \mathrm{H}_{0}: \mu \mathrm{A}_{1} \leq \mu \mathrm{A}_{2}$

$\mathrm{H}_{\mathrm{a}}: \mu \mathrm{A}_{1}>\mu \mathrm{A}_{2}$

Hypothesis II $\quad \mathrm{H}_{0}: \mu \mathrm{B}_{1} \leq \mu \mathrm{B}_{2}$

$\mathrm{H}_{\mathrm{a}}: \mu \mathrm{B}_{1}>\mu \mathrm{B}_{2}$ 
TABLE II.TESTING HYPOTHESIS BY USING 2 WAY ANAVA

\begin{tabular}{|l|l|l|l|l|l|}
\hline Varians & $\mathrm{Dk}$ & $\mathrm{JK}$ & $\mathrm{RJK}$ & $\mathrm{F}_{\text {Hitung }}$ & $\mathrm{F}_{\text {Tabel }}$ \\
\hline $\mathrm{A}$ & 1 & 20437,48 & 20437,48 & 5,01 & 4,01 \\
\hline $\mathrm{B}$ & 1 & 19926,68 & 19926,68 & 4,88 & 4,01 \\
\hline $\mathrm{AB}$ & 1 & 28360,09 & 28360,09 & 6,96 & 4,01 \\
\hline Galat & 56 & 228223,2 & 4075,41 & - & - \\
\hline Total & 59 & 248149,9 & 72799,66 & - & - \\
\hline
\end{tabular}

Where,

A : Learning Models

B : Achievement Motivation

Dk : Degree of freedom

JK : The sum of squares

RJK : The average of the sum of squares

The interaction can be seen in figure. 1

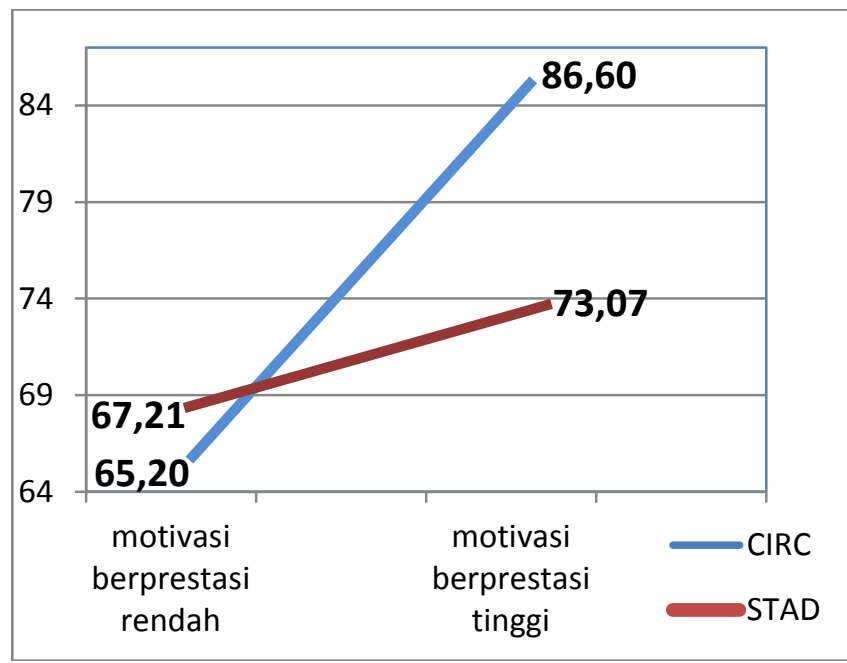

Fig1. Interaction of Learning Models and Achievement Motivation

\section{RESUlT AND DISCUSSION}

Based on the results of testing the first hypothesis, the results of the calculation of the hypothesis obtained $\mathrm{F}$ count $=$ 5.01. For the distribution value of $\mathrm{F}$ table $=4.01$ then this result shows that $\mathrm{F}$ count $>\mathrm{F}$ table so that it gives a decision that $\mathrm{Ho}$ is rejected and $\mathrm{Ha}$ is accepted. Thus, the proposed research hypothesis that is the ability to read narrative text in English class CIRC learning model students is higher than the ability to read narrative text in English students STAD learning model class.

This is in line with the results of Febriyanto's study (2016) which states that there is an increase in student learning outcomes using the CIRC learning model. According to Febriyanto's research, the CIRC learning model provides opportunities and opportunities for students to think more and reason about what students are learning. This model also encourages students to do comprehension reading skills, such as observing, asking questions, gathering information, associating, and communicating. Where students here are required to be active in doing these skills in person. The CIRC model can also develop students' attitudes, skills and knowledge. The application of the CIRC model in learning not only focuses on how to develop students' competencies in conducting observations or experiments, but how to develop their knowledge and thinking skills so that they can support creative activities in innovating or working. Through a series of learning using the CIRC model, student learning outcomes include the cognitive, affective, and psychomotor domains can be trained.

While the STAD Model is a model that prioritizes teaching objectives that emphasize language function as a communication tool. The focus of the STAD model lies in how language is used as a communication tool not about grammatical structure. Even though students' reading ability in school is not only about students' language / proficiency in mastering the language but also students' understanding of grammar structure.

From the description above, it can be seen that students' reading abilities related to cognitive aspects are highly developed in the CIRC learning model. Thus, it is clear that using the CIRC learning model will give a better influence on the ability to read narrative text in English compared to learning using the STAD learning model.

From the results of the calculation of the second hypothesis obtained $\mathrm{F}$ count $=4.88$. For the distribution value of $\mathrm{F}$ table $=4.01$, this result shows that $\mathrm{F}$ counts $>\mathrm{F}$ table so that it gives a decision that Ho is rejected and $\mathrm{Ha}$ is accepted. Thus, the research hypothesis proposed is that there are differences in the ability to read narrative texts in English with students with high achievement motivation and the ability to read narrative texts in English students with low achievement motivation. The results showed that the average value of the ability to read narrative texts in English students who had high achievement motivation was higher than those who had low achievement motivation. This indicates that students who have high achievement motivation are better able to understand English language reading than students who have low achievement motivation. Researchers observed during the learning process, it appears that students who are classified as having high achievement motivation tend to be more sociable, mingle with new environments, active in groups and personally, more motivated and enthusiastic about learning, more confident in asking questions, answering questions, expressing opinion. Students who have high achievement motivation also do not feel afraid of being wrong or having different opinions with other students and have more mutual respect.

Based on the description above, it is clear that students who have high achievement motivation have the ability to read narrative texts in higher English than students who have low achievement motivation. It can be concluded if there are differences in the ability to read narrative texts in English, students who have high achievement motivation with low achievement motivation.

From the results of the calculation of the third hypothesis obtained $\mathrm{F}$ count $=6.96$. For the distribution value of $\mathrm{F}$ table $=$ 4.01 , this result shows that $\mathrm{F}$ counts $>\mathrm{F}$ table so that it gives a 
decision that Ho is rejected and $\mathrm{Ha}$ is accepted. Thus, the research hypothesis proposed is that there is an interaction between learning models and Achievement Motivation on the ability to read narrative texts in English. When viewed from the average ability to read narrative text in English in groups of students who have high achievement motivation and are taught with the CIRC learning model, it is higher than the average ability to read narrative texts of other student groups. This is because students can follow the learning well, where students are able to solve the proposed problem. The existence of a learning model that can foster the spirit of students in learning. Meanwhile, in teaching and learning activities, either in the CIRC learning model or the STAD learning model can take place interactively because of the pleasant learning atmosphere.

Learning using the teacher's CIRC learning model is no longer a learning center but is student-centered. That is, the CIRC learning model is intended to provide understanding to students in recognizing, understanding various materials using a scientific approach, that information can come from anywhere, at any time, not depending on the direction of the teacher's information. The essence of this model expects students to make the process of observing, asking, reasoning, trying, communicating (networking) everything related to the learning process itself. Through this model students are expected to think scientifically and can learn and work in groups solving problems given by the teacher so as to achieve optimal learning achievement. One of the things that need to be considered also in the factors that influence the ability to read narrative texts in English is Achievement Motivation. Motivation Achieving students who are less known by the teacher as a whole will be difficult to direct students to be active in learning activities. This condition causes the ability to read narrative texts in English, students are still much below average.

\section{REFERENCES}

[1] Agus, Suprijono. (2010). Cooperative Learning. Yogyakarta: Pustaka Pelajar

[2] Anam, Khoirul. (2016). Pembelajaran Berbasis Inkuiri Metode dan aplikasi. Yogyakarta: Pustaka Pelajar.

[3] Arikunto. (2010). Prosedur Penelitian: Suatu Pendekatan Praktek. Jakarta: Rineka Cipta

[4] Astuti, Ika. (2015). Penerapan Model STAD Untuk Meningkatkan Kemampuan Mengidentifikasi Teks Naratif. Jurnal.

[5] Bakri, Yusman. (2014). Penerapan Model Pembelajaran Kooperatif Tipe STAD Untuk Meningkatkan Kemampuan Membaca Dalam Memahami Isi Cerita Pendek Pada Siswa Kelas V SDN 25 Ampana .Jurnal.

[6] Brophy, J. (2004). Motivating Students to Learning, Lawrence Erlbaum Associates. New Jersey.

[7] Daryanto. (2016). Media Pembelajaran. Yogyakarta: Penerbit Gava Media.

[8] Dimyati dan Mudjiono. (2009). Belajar dan Pembelajaran. Jakarta: PT Rineka Cipta.

[9] Ekawati, Risma. (2015). Peningkatan Hasil Belajar Dan Kemampuan Berpikir Kritis Dengan Model Pembelajaran Cooperative Integrated Reading And Composition. Jurnal.
[10] Febriyanto, Budi. (2016). Penerapan Model Cooperative Integrated Reading And Composition Dalam Pembelajaran Keterampilan Membaca Pemahaman. Jurnal.

[11] Hamalik, Oemar. (2006). Proses Belajar Mengajar. Jakarta: PT Bumi Aksara.

[12] Hamzah B. Uno. (2008). Teori Motivasi dan Pengukurannya Analisis di Bidang Pendidikan. Jakarta: PT Bumi Aksara.

[13] Karim, Abd. (2016). Penerapan Pembelajaran Model Cooperative Integrated Reading And Composition (CIRC) Untuk Meningkatkan Hasil Belajar Siswa Kelas VIII Materi Membaca Teks Dan Esei Berbentuk Descriptive Pelajaran Bahasa Inggris Pada SMP Negeri 3 Kluet Utara. Jurnal.

[14] Luthans, Fred. (1995). Organizational Behavior. Sixth edition. Mc Graw-Hill International Edition. New York: Management series.

[15] Maidiyah (1998). Metode Mengajar. Jakarta: Gramedia

[16] Mulyasa. (2013). Pengembangan dan Implementasi Kurikulum 2013. Bandung: PT Remaja Rosdakarya

[17] Munandar, S.C. Utami. (1992). Mengembangkan Bakat Anak. Jakarta: Gramedia.

[18] Munawaroh. (2013). The Effect of Type Stad Cooperative Learning Model, the Way of Learning, And Learning Motivation toward Enterpreneurial Attitudes (A case Study in SMK N I Jombang. Jurnal.

[19] Nana Sudjana. (1987). Cara Belajar Siswa Aktif. Bandung: Banu Algesindo.

[20] Nasution. (2006). Berbagai Pendekatan Dalam Proses Belajar Mengajar. Jakarta: Bumi Aksara

[21] Ngalimun.(2012). Strategidan Model Pembelajaran. Banjarmasin: Aswaja Pressindo. 